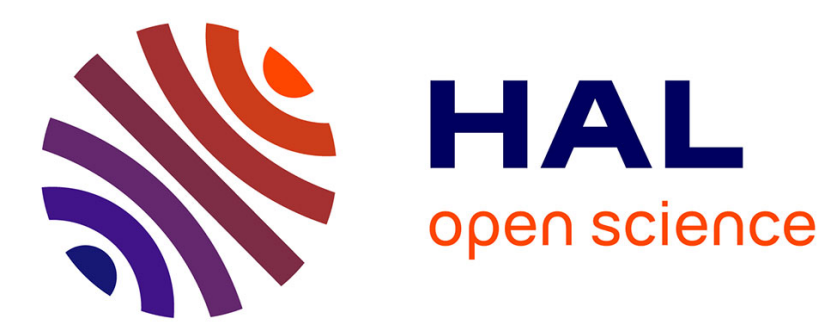

\title{
Nàxī language / Naish languages
}

Alexis Michaud, Limin He, Yaoping Zhong

\section{To cite this version:}

Alexis Michaud, Limin He, Yaoping Zhong. Nàxī language / Naish languages. Encyclopedia of Chinese Language and Linguistics, 3, Brill, pp.144-157, 2017, 10.1163/2210-7363_ecll_COM_00000247 . halshs-00793649v2

\section{HAL Id: halshs-00793649 \\ https://shs.hal.science/halshs-00793649v2}

Submitted on 4 Jan 2017

HAL is a multi-disciplinary open access archive for the deposit and dissemination of scientific research documents, whether they are published or not. The documents may come from teaching and research institutions in France or abroad, or from public or private research centers.
L'archive ouverte pluridisciplinaire HAL, est destinée au dépôt et à la diffusion de documents scientifiques de niveau recherche, publiés ou non, émanant des établissements d'enseignement et de recherche français ou étrangers, des laboratoires publics ou privés.

\section{(1)(1) $\$(0)$}

Distributed under a Creative Commons Attribution - NonCommercial - ShareAlikel 4.0 
References: MICHAUD Alexis, HE Limin \& ZHONG Yaoping (2017). “Nàxī 納西 language / Naish languages.” In: Rint Sybesma, Wolfgang Behr, Zev Handel \& C.T. James Huang (eds.), Encyclopedia of Chinese Language and Linguistics. Leiden: Brill. Volume 3, pages $144-157$.

\section{Nàxī 納西 language / Naish languages}

Alexis Michaud 米可 (CNRS-LACITO), with two co-authors for the section on Naxi pictographs: Hé Lìmín 和力民 (Dongba Culture Research Institute, Lijiang) and Zhōng Yàopíng 钟耀萍 (Chinese Academy of Social Sciences, Beijing)

\section{General}

\subsection{Definition and genealogical position}

'Naxi' (Nàxī 納西) is commonly used in Chinese scholarship as a cover term for a range of language varieties related to the Naxi language as spoken in Lìjiāng 麗江, in Northwestern Yunnan. The same usage was followed until recently in the Ethnologue inventory of languages (code: NBF). The diversity of this set of 'dialects' or 'languages' is increasingly recognized, however; witness the creation of two distinct entries in Ethnologue as from May 2011: NXQ for Lijiang Naxi ('Naxi proper'), and NRU for Na/Narua. The latter variety is also referred to as Mósuō 摩梭, taking up a name formerly used for Naxi in Chinese chronicles, whose textually-attested variant forms include Mósuō 摩娑, Móshā 摩沙, Móxiē 麼些, Móxiē 磨些 and Mòxiē 末些 (see Bacot 1913; Fu Maoji 1940; Jacques and Michaud 2011). The technical term 'Naish', based on the endonym [na], is used here for this entire low-level grouping within Sino-Tibetan, i.e. covering the same speech varieties as 'Naxi 


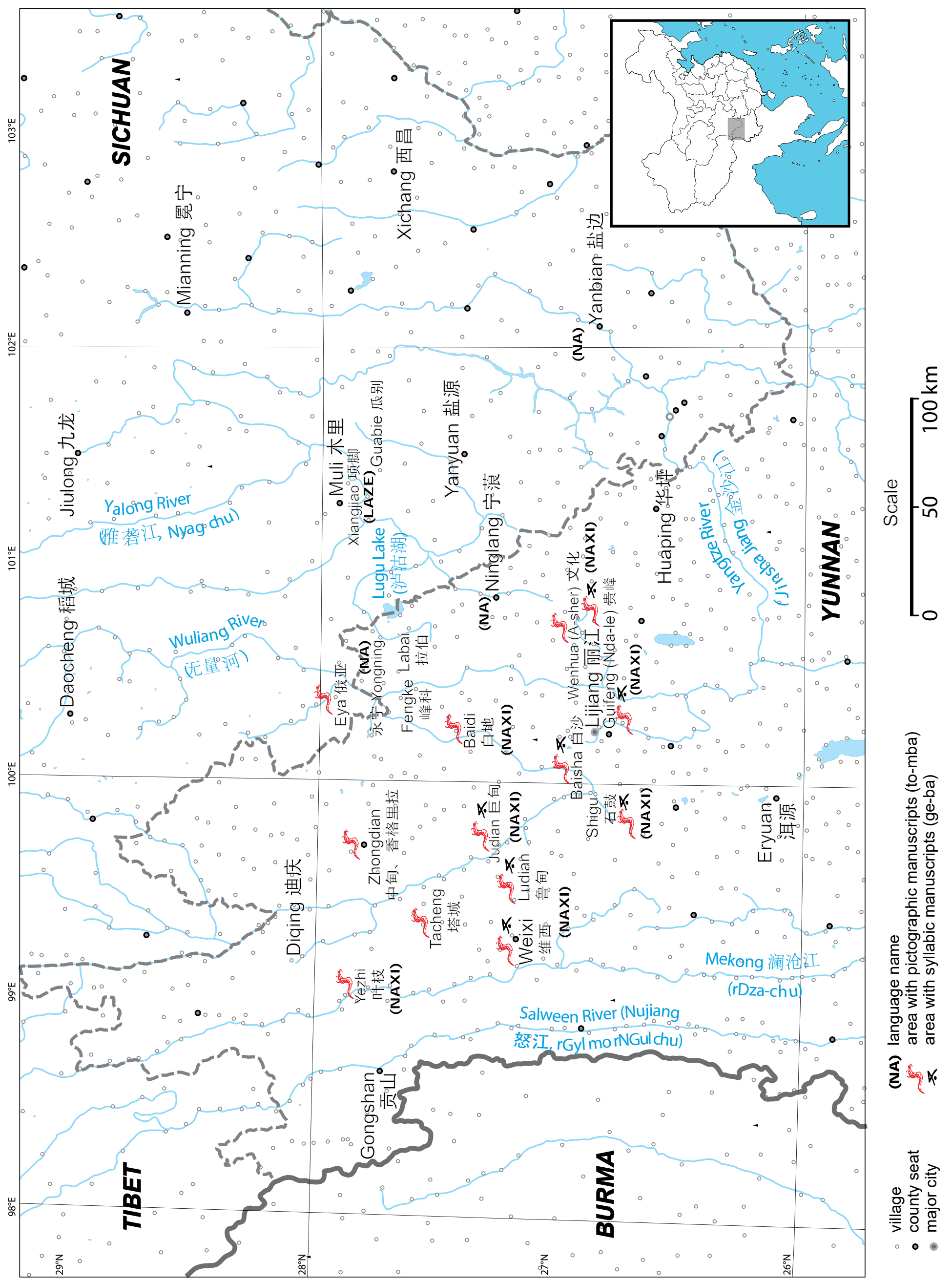


dialects' (Nàxīyǔ fāngyán 纳西语方言) in Chinese scholarship, and as the former language code NBF.

Naish was originally classified within the Yi (Loloish) branch (Shafer 1955). It has since been shown that it does not partake in the innovations that characterize Loloish (Bradley 1975). The classification of Naxi as part of $\mathrm{Yi}$ is nonetheless periodically reaffirmed in China (for instance by Gài Xìngzhī 蓋興之 and Jiāng Zhúyí 姜竹儀 1990, and Lǐ Yǒngsuì 李永燧 2010:21-22) on the basis of some surface phonetic similarities in the vocabulary and some similar syntactic characteristics. Historical work on this area of Sino-Tibetan is still in its early stages for want of in-depth documentation. Preliminary comparative work suggests that the Naish languages are related, in decreasing order of closeness, to: Shixing and Namuyi; Ersu, Lizu, and Tosu; Pumi, Rgyalrongic, Tangut and other languages currently labeled "Qiangic"; and Lolo-Burmese (Jacques and Michaud 2011).

\subsection{Geographic distribution}

The Naish languages are spoken in an area that straddles the Yunnan-Sichuan border: Lijiang Municipality and the neighboring prefectures of Yányuán 鹽源, Yánbiān 鹽邊, Mùlǐ 木裡 and Díqìng 迪慶 (see map). An ethno-historical survey is provided by Guō Dàliè 郭大 烈 and Hé Zhìwǔ 和志武 (1994:4-7), and a linguistic overview by Hé Jírén 和即仁 and Jiāng Zhúyí 姜竹儀 (1985:104-116), who distinguish (i) a relatively homogeneous Western dialect area, coinciding by and large with the extension of the domain of the Mù 木 feudal lords in the Ming dynasty, and (ii) a more diverse Eastern area; for an overview of the latter, see Yáng Zhènhóng 楊振紅 (2009). The Yangtze River is an important - though by no means impassable - boundary between the two areas. The greatest linguistic diversity is found aroundYǒngníng 永寧, within a radius of less than $100 \mathrm{~km}$. Interestingly, Yongning is called "land of the center, heartland" in Naish (Lijiang Naxi: /lyłdy」/, Yongning Na: /4itdiJ/). The map shows the location of the three varieties from which illustrations will be drawn in this article: Lijiang Naxi as spoken in the village of A-sher; Yongning Na; and Laze. It also presents the geographic distribution of the Naxi scripts.

Naish endonyms offer an illustration of dialectal diversification. $\mathrm{Na}$ is called /na $-\mathrm{z} w \mathrm{w}-1 /$ : the endonym plus the word for 'language; to speak'. The Naxi endonym has incorporated the 
word for 'man, person', /hit/: the people are /na 」hi-// and their language /na 」hi--ku-ttsul」/ 'language of the Naxi'. According to Guō Dàliè 郭大烈 and Hé Zhìwǔ 和志武 (1994:4-7), Laze /latze-t/ is the name of the place from where this group of people migrated some eight generations ago. Such lexical innovations, added to the great number of homophonous syllables, make cross-dialect communication challenging. In practice, speakers resort to the lingua franca of their area: now dialects of Mandarin Chinese; previously Lijiang Naxi in the Lijiang plain, Na around Yongning, Pumi in Muli, etc.

\subsection{The speakers of Naish languages}

Speakers of Naish languages number about 300,000. Eastern dialects typically have the fewest speakers: less than 1,000 for Laze, and less than 10,000 for Na. Language shift to Mandarin Chinese is under way ( $\operatorname{Lidz} 2010,19-20)$. There is a wide generation gap in language proficiency; for detailed examples in Na, see Michaud and Latami Dashi 2011.

The correlation between languages and ethnic designations varies between provinces: different teams operated in Yunnan and Sichuan when 'nationalities' (mínzú 民族) were assigned. In Yunnan, there is a good fit between the official ethnic designation 'Naxi' and use of a Naish language - except for the growing part of the population which has shifted to speaking Chinese but remains part of the 'Naxi nationality'. In Sichuan, on the other hand, only the relatively small groups of settlers who moved in from Lijiang in recent times and speak Lijiang Naxi were classified as 'Naxi', such as the population of the village of Éyà 俄 亞 (see map). The older Naish-speaking population stratum received the label 'Mongolian' instead (Měnggǔzú 蒙古族); this paradoxical choice was no doubt influenced by the powerful ring which the name 'Mongolian' retains in the area since the Mongolian army's impressive crossing of the Himalayas (passing through Yongning), invasion of the kingdom of Nánzhào 南詔, and victory over the Song dynasty. Initially the 'Mongolian' label was taken very seriously and attempts were made to teach the Mongolian script to Naish speakers of Sichuan, with predictably poor results. The initial ethnic identification was not modified since, because of a national policy to keep the Pandora's box of ethnic labels closed whenever possible. 
The main traditional activity of Naish-speaking peoples was agriculture, as well as trade in some areas. Tourism has developed at a staggering pace since the 1990s, leading many young people to leave agriculture and engage in the tourist service industry, and speeding up the influx of non-Naish migrants to the area.

\subsection{State of research}

Overall, Naish languages are relatively little-described; numerous varieties remain fully undescribed. One of the aims of the present overview is to bring out perspectives for documentation and research.

Monolingual materials in romanized Lijiang Naxi (folk tales, songs, and materials translated from Chinese) were published in the 1980s but not actively circulated. The presence of numerous typographic errors restricts their usefulness for research. A journal in Romanized Naxi, Lijiāng Nàxīwén bào 《丽江纳西文报》 (Lijiang Naxi Script Journal), was also published starting in 1985, largely thanks to the efforts of Ms. Hé Jiézhēn 和洁珍. Eightytwo issues came out before publication was suspended in 2003. This was the longest-lasting effort at giving Naxi a place (however modest) in the media, in a context where the use of languages other than Chinese is strongly discouraged, being perceived as a threat to national unity.

In-depth lexicographic work on Lijiang Naxi by T. Pinson will soon result in the publication of a dictionary, considerably expanding the existing glossary (Pinson 1998). For Na, a comprehensive grammar is available (Lidz 2010). Publications in Chinese include a collection of articles by the Naxi linguist Hé Jírén 和即仁 (2006) and a collection of proverbs (Hé Jiézhēn 和洁珍 2009). Word lists for various Naish language varieties are available online from the Sino-Tibetan Etymological Dictionary and Thesaurus (http://stedt.berkeley.edu), which has collected them from a variety of published and unpublished sources. Fully-glossed Naxi, $\mathrm{Na}$ and Laze texts and word lists synchronized with recordings are available from the Pangloss Collection, the open archive of the LACITO laboratory (http://lacito.vjf.cnrs.fr/archivage/presentation_en.htm); they are perennially archived and will therefore remain accessible in future. There also exist extensive collections of unique materials in private collections (in particular that of the Naxi scholar Gē Āgān $\mathbb{E}$ 
阿干), which are under threat of being scattered for want of coordination with institutional repositories.

\section{Description of the language}

Note: unless otherwise indicated, the examples are from Lijiang Naxi as spoken in A-sher (see map). For the sake of phonetic transparency, the transcription is not entirely phonemicized; for details on the phonemic analysis see Michailovsky and Michaud 2006.

\subsection{Phonology}

\subsubsection{Consonants}

i. Inventory

\begin{tabular}{|l|l|l|l|l|l|l|}
\hline & bilabials & dentals & retroflexes & palatals & velars & glottals \\
\hline stops & $\mathrm{p}^{\mathrm{h}} \mathrm{p} \mathrm{b}^{\mathrm{m}} \mathrm{b}$ & $\mathrm{t}^{\mathrm{h}} \mathrm{t}^{\mathrm{n}} \mathrm{d}$ & $\mathrm{t}^{\mathrm{h}} \mathrm{t} \mathrm{d}{ }^{\mathrm{n}} \mathrm{d}$ & & $\mathrm{k}^{\mathrm{h}} \mathrm{k} \mathrm{g}^{\mathrm{n}} \mathrm{g}$ & \\
\hline affricates & & $\mathrm{ts}^{\mathrm{h}} \mathrm{ts} \mathrm{dz}{ }^{\mathrm{n}} \mathrm{dz}$ & $\mathrm{ts}^{\mathrm{h}} \mathrm{ts} \mathrm{dz}{ }^{\mathrm{n}} \mathrm{dz}$ & & & \\
\hline fricatives & $\mathrm{s} \mathrm{z}$ & $\mathrm{s} \mathrm{z}$ & $\mathrm{c}$ & & $\mathrm{h}$ \\
\hline nasals & $\mathrm{m}$ & $\mathrm{n}$ & $\mathrm{l}$ & & $\mathrm{y}$ & \\
\hline lateral approximants & & $\mathrm{l}$ & & & \\
\hline
\end{tabular}

\section{ii. Distribution}

Some phonemic oppositions are massively neutralized: for instance, retroflex stops and the retroflex approximant are only contrastive in one single context (in front of $/ \mathrm{o} /$ ), as are the palatal and glottal fricative (in front of $/ y /$ ). A representation in terms of existing syllables provides a more revealing picture than an inventory of consonants and vowels: see Michailovsky and Michaud 2006, and Michaud and Jacques 2012 on Laze.

\subsubsection{Vowels}

Naxi has a crowded back vowel space: / $\mathrm{u}$ u $\gamma$ o a $\curvearrowright^{\curvearrowright} \mathrm{v} / \mathrm{plus} / \mathrm{w} \gamma \mathrm{w} \curvearrowright^{\sim} \mathrm{wa} /$ and $/ \mathrm{j} \gamma \mathrm{ja} /$. Its front vowels are /i y e æ/ plus /ue wæ/.

Mandarin loanwords are adding to the stock of syllables with on-glides, creating new glide + vowel combinations, and introducing off-glides. This does not warrant the conclusion that all glides were introduced through borrowings, however: there is no evidence that any Naish language had a simple CV structure at any point. 


\subsubsection{Syllable}

The phonology of Naish languages is highly eroded, as compared to the rich syllabic canon of conservative Sino-Tibetan languages. Naish languages underwent strict monosyllabification and a dramatic simplification of its syllable structure, to $C(G) V+T$, where $\mathrm{G}$ is an on-glide and $\mathrm{T}$ a tone. Extreme coarticulation within syllables is common, e.g. /by/ is realized as [B] ; in $\mathrm{Na}$ and Laze, which have nasal vowels after initial /h/, the entire syllable is realized with nasalization.

The synchronic distribution of vowels with respect to initials makes good historical sense: in several cases, it still reflects straightforwardly the conditioning that created new contrastive vowels. For instance, the only context where there is a phonemic contrast between /i/ and /e/ in Yongning $\mathrm{Na}$ and in Laze is after coronal fricatives and affricates. (For instance: $\mathrm{Na} / \mathrm{si}$ / 'wood', /se $7 /$ 'to walk'.) The diachronic reason why the distribution of /e/ is so restricted in $\mathrm{Na}$ and Laze is that it originates from *a after coronal fricatives and affricates (for details see Jacques and Michaud 2011).

\subsubsection{Tones}

\section{i. inventory}

Tones in Naish languages consist simply of pitch distinctions, on a three-level scale: High, Mid and Low, without phonation-type characteristics. Contours are made up of sequences of tone levels realized on a single syllable. A notation based on the 5-point pitch scale is adequate (tones $/ 5 /, / 3 /$ and $/ 1 /$, from highest to lowest), and allows for a description of tone sequences: e.g. /35/ for a Mid-to-High rise (as in Laze $/ \mathrm{t}^{\mathrm{h}} \mathfrak{x}^{35} /$ 'to bite'). The symbols used here are tone-letters which represent visually the tonal levels: 1 High, $\dashv$ Mid, $\lrcorner$ Low, $\lambda$ Lowto-Mid, 1 Mid-to-High. No Naish language has distinctive falling contours (sequences in which the second tone level is lower than the first) on monosyllables.

In Yongning $\mathrm{Na}$ and Laze, there is overwhelming evidence from alternations showing that contours consist of sequences of levels: for instance, $\mathrm{Na} / \mathrm{z}^{2}-1 /$ 'to laugh' plus the immediate future /bit/ (grammaticalized from 'to go') yields /zææ-t-bit/ whereas /la1/ 'to strike' yields /lat-bi $7 /$, where the $\mathrm{H}$ part of the verb's MH contour reassociates to the following syllable. There is also some evidence for the decomposition of contours in Naxi, but the everincreasing influence of Chinese on this language is towards the reinterpretation of tone sequences (phonetically realized as contours) as unitary (non-decomposable) contour tones.

\section{ii. Distribution and historical remarks on the inventory}


Lijiang Naxi simply has one tone per syllable, with very few processes of tonal reassociation. Laze is more complex tonally, and $\mathrm{Na}$ has the most complex tone system found among Naish languages so far. All syllables have tone in the surface phonological representation in $\mathrm{Na}$ and Laze, although some bound morphemes do not have a tone of their own.

The origins of tones in Naish are not understood in detail yet. Among the four tones of Naxi, the rising tone is marginal, and is clearly an innovation (Michaud 2006; Michaud and $\mathrm{He}$ Xueguang 2007). The Mid and Low tones are the most common and probably derive from an original two-way split. The High tone appears to have developed later, from the simplification of initial clusters: it is especially frequent on verbs, where the hypothesized clusters may have resulted from prefixation.

\subsubsection{Phonotactics}

There is a tendency towards regressive vowel harmony within disyllabic words, which becomes sporadically lexicalized (Lidz 2010, 96-105; 155). In some cases, this results in new CV combinations, e.g. /sie/ in Laze /sietliełmiet/ ' $7^{\text {th }}$ month' (from /su-t/ 'seven' and /lie-mie-1/ 'moon; month'). Naxi /kułtsul/ 'to speak; language' appears to be an instance of vowel harmony in light of comparison with the $\mathrm{Na}$ form $/ \mathrm{kr}-\mathrm{tsu} \mathrm{J} /$.

Among other peculiarities of the Naish languages, Laze makes fascinating use of allophonic variation of voiced stops and affricates to signal morphosyntactic junctures. These voiced consonants devoice (though not completely) in medial position within a lexically disyllabic word, and conversely, are realized as prenasalized at a juncture between morphemes within

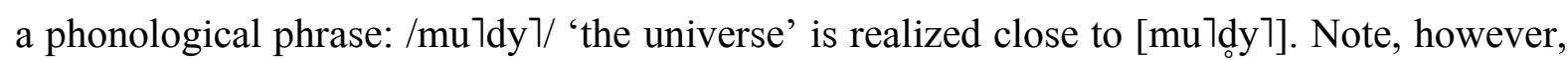
that this is a tendency, not a hard-and-fast rule neutralizing voicing contrasts in this position. Voiced realizations are occasionally heard, and speakers are able to produce a hyperarticulated rendering with full voicing. Conversely, the sequence /nie1 grt/, 'because of this', made up of the two morphemes 'thus, in this way' and 'since, as', is realized as $\left[\right.$ nie $\left.{ }^{\mathrm{n}} \mathrm{g} \mathrm{g}\right\rfloor$. Numerous examples can be observed in the annotated recordings available online.

\subsection{Lexicon}

Many of the lexical complexities of Naish languages result from the creation of disyllables out of monosyllabic roots, through reduplication, compounding and affixation. In Lijiang Naxi, the word for 'language; to speak' (which has both nominal and verbal uses), /ku-tsul $\mathrm{J} /$, is disyllabic and not divisible. In $\mathrm{Na}$, on the other hand, it is divisible:

$$
\begin{array}{ll}
\text { hĩ--ki- } & \mathrm{kr}-1<\mathrm{m} ə \mathrm{\jmath}>\text { tsw }\rfloor \\
\text { person-dat } & \text { speak }<\text { neg }>
\end{array}
$$

'to keep [something] secret, not to tell people'. 
Loanwords: Tibetan cultural influence in the area is strong; however, relatively few borrowings from Tibetan are found outside of specific spheres such as religion and proper names. Chinese sources show that contacts with Chinese speakers occurred as early as the Han dynasty; they resumed in the Tang dynasty, and have been increasingly strong and direct since the Yuan dynasty. Chinese borrowings undergo various degrees of phonological and lexical accommodation depending on the speakers' proficiency in Chinese; this also allows for several stylistic options. For instance, 'Westerner' translates into $\mathrm{Na}$ as /je」ze-t/ (from Chinese yángrén 洋人), or as /je」z̨et-hĩ $7 /$, adding the Na word for 'man', /hĩ $7 /$ In the first case, the borrowing is processed as a disyllabic noun phrase, as in Chinese. This manifests the speaker's command of that language, and the expectation of similar abilities on the listener's side: Chinese is used as part of the speech act participants' common ground. In the second case, it is treated as one single morpheme, meaning 'foreign'; this emphasizes the speech act participants' $\mathrm{Na}$ common ground.

\subsection{Morphology}

There is no inflectional morphology in Naish. Suppletion is observed between past and nonpast forms for 'to go' (Na: /bit/ vs. /huJ/; Laze: /bit/ vs. /hut/; Lijiang Naxi: /but/ vs. /hut/). Grammatically conditioned tone change is ubiquitous in Na, e.g. in compounds: the determinative compound /zwwæ-zot-gvtdv 7 ' colt's back' has a final $\mathrm{H}$ tone, whereas the coordinative compound 'father and mother', which has the same input tones, is /atdatəłmi\# $1 /$, with a floating $\mathrm{H}$ tone (a tone which can only associate to a following syllable; it is represented as \#1). Reduplication of verbs and adjectives is widely used to convey reflexivity and intensification (on Naxi: Michaud and Vaissière 2007), e.g. /la // 'to strike',

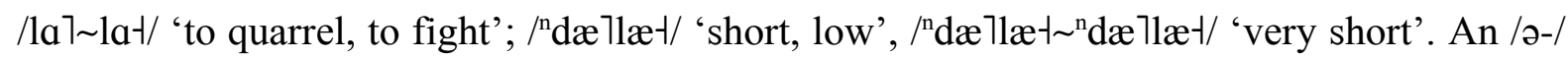
prefix is used in kinship terms referring to one's elders.

A major driving force towards the creation of disyllables is the pressure of homophony, caused by the dramatic phonological erosion of the Naish languages. In $\mathrm{Na}$, /i $7 /$, realized [ji-], can mean 'jar'; 'ox'; 'to do'; 'to draw'; and 'to inform'. 'Jar' is generally disyllabic: /itmi $t /$, adding the syllable for 'mother', which has grammaticalized uses to mean 'female', and 'large' (as opposed to 'small' for 'son; male' - this is widespread in the Himalayas: see Mazaudon 2003 on Tamang, and a cross-language discussion by Matisoff 1992). In that 
instance, the suffixed syllable does not carry any added meaning: the disyllabic form simply replaces the monosyllable.

\subsection{Syntax}

\subsubsection{Sentence}

\subsubsection{Word order}

Word order is $\mathrm{S}+\mathrm{O}+\mathrm{V}$. Adverbials can appear at various places. Particles indicating semantic roles are not obligatory; they play a major role in the expression of logical relations, and allow for a deviation from standard word order, as in (2), where the subject (explicitly marked as such) appears after the object. (The topic marker can be removed from this sentence, whereas the agent marker cannot.) Verb serialization is common.

\begin{tabular}{|c|c|c|c|c|c|c|}
\hline \multirow[t]{2}{*}{ (2) } & $\mathrm{t}^{\mathrm{h}} \mathrm{w} 7-\mathrm{se} 7$, & \multicolumn{3}{|c|}{ sjatho-tsu- } & zot & 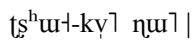 \\
\hline & thus-cond/top & \multicolumn{3}{|c|}{ young_man(borrowing) } & $\operatorname{man}$ & deict.prox-cl \\
\hline bu」-met & șu--ts $\left.{ }^{\mathrm{h}} u\right\rfloor-\eta \underline{\omega-1}$ | & $\left.\operatorname{ts}^{\mathrm{h}} \mathrm{a}\right\rceil$ & $-{ }^{n} \mathrm{dzu}-1$ & $\mathrm{mrt}$ & $-\mathrm{mæ-1} !$ & \\
\hline sow & were/vampire & agt & bite & eat & neg & achieve \\
\hline
\end{tabular}

"And so the weresow did not manage to devour that young fellow!"

(Lijiang Naxi, consultant M4, last sentence of Weresow story)

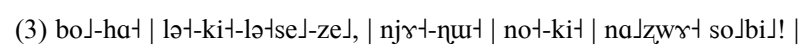

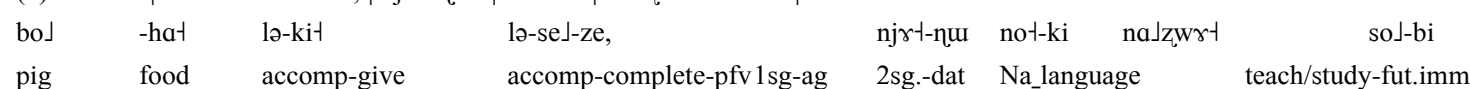

"After feeding the pigs, I will teach you Na (myself) !/ I will come over for a language lesson!" (Yongning Na, speaker F4; sentence transcribed on the fly, 2008)

The context of (3) is the following: the speaker saw me sitting ready for an elicitation session, silently hoping that someone could give me some of their time. There was a real uncertainty as to who that would be, as I was working with two consultants within the household at the time. No subject is indicated in the first part of the sentence ("After feeding the pigs"), as this is obvious from the situation. On the other hand, the explicit mention of both semantic roles in the second part of the sentence thoroughly answers the concerns of its addressee.

As is well-attested across the Himalayas, nominals, including pronouns, need not appear if they can be understood from the discourse context. This applies to any definite argument of the verb, the head of a relative clause, or the head of a complex noun phrase. 
(8) lat-dzu1 | biłmił go」 accomp-to eat stomach ache

"if (you) eat (of it), (your) stomach (will) hurt!" (Na, speaker F4. Context: on the mountain, pointing out a berry that is not edible.)

The adverbializer is /be-t/ in Naxi, probably grammaticalized from the verb /be-t/ 'to do': /ts ${ }^{\mathrm{h}} \mathrm{wa} /$ ' 'fast', /ts ${ }^{\mathrm{h}} \mathrm{wa} J-b e-/$ 'rapidly'. It is /vie-// in Laze (cognate with Naxi) and /zo/ in Na (non-cognate).

As in Limbu and other Himalayan languages, topic markers are the morphemes with the highest frequency of occurrence.

\subsubsection{Tense, aspect and mood}

Tense, aspect and mood are expressed through a host of post-verbal particles and some preverbal particles: durative $\left./ \mathrm{t}^{\mathrm{h}} \mathrm{e}\right\rfloor$-/, accomplished /le--/, perfective /-se $J /$, experiential /-gi/. 'To go', /but/, is grammaticalized to express immediate future, and /se-t/ 'to complete' as a completion marker (both are placed post-verbally). Combinations among these particles create a wealth of highly dialect-specific nuances; these nuances are best appreciated by examining examples in context.

\subsubsection{Question formation}

In yes/no questions, the verb is preceded by an interrogative adverb (Naxi / / $7 /, \mathrm{Na} / \mathrm{o} /$, Laze /a/): / th $u-1$ o $7-b u-1 /$ 'Is he going?' Naxi uses sentence-final /la $7 /$ in calls for confirmation: $/ t^{\mathrm{h}} \mathrm{w}+\mathrm{bu}-\mathrm{-la} / /$ 'He's going, right?' In wh-questions, the interrogative pronoun occupies the same slot as the noun phrase would in a statement.

\subsubsection{Existential sentences}

There exist several existential verbs, as is common in the area: four are reported in $\mathrm{Na}$ (Lidz 2010, 356-361); Naxi has /it/ ([ji-] ) for noncount nouns (e.g. 'there is rice in the granary'), /gy / ([fy」] ) for count nouns (e.g. 'there is someone at home/in the house'), and /gy-/ ([fy-1]) for existence/possession (e.g. 'there is a book/I have a book'):

(4) tja $\mathrm{i}-\mathrm{-}-\mathrm{se}\lrcorner$ !

electricity + existential + perfective

'There is electricity again! / Power cut is over!' (2002 field notes) 
(5) ja-ko」 k $\mathrm{h}-\mathrm{m} \gamma-1-\mathrm{ggy}\rfloor$ !

house/home $+\operatorname{dog}+$ neg + existential

'There is no dog at home!/We don't have a dog at home!' (explanation provided to a firsttime visitor who was anxious about watchdogs; 2002 field notes)

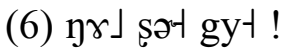

1sg + occupation/work + existential

'I'm busy! / I have work to do!'

\subsubsection{Sentence-final particles and intonation}

Among sentence-final particles, several are epistemics or evidentials: in Naxi, /tsul/ for hearsay, /j $\mathrm{j}-$ / for direct observation; /my $\rfloor /$ for affirmation, /me-t/ for exclamation, and /mad/ to convey obviousness. Particles carry a tone but are weaker than lexical words and

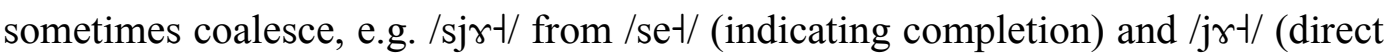
observation).(The analysis as /se J/ PFV +/jrt/ proposed by Hé 和 and Jiāng 姜 1985 does not accord with consultants' intuitions.) Combinations between sentence-final particles allow for a considerable range of highly dialect-specific nuances. The final meaning obtains through an interplay with intonational cues: the three-level tone system does not considerably constrain a sentence's intonation; it leaves ample room for the expression of nuances of doubt, surprise and other attitudes and emotions by intonational means (overall raising of the pitch register, pitch range expansion, lengthening, changes in phonation type, etc.).

\subsubsection{Noun and noun phrase}

The classifier, preceded by a numeral or a demonstrative, follows the noun:

(7) ...mi $\left.\rceil-k i\rceil t s^{h} u--k v\right\rceil g r-1 ~ s æ-\ldots$.

$\begin{array}{llllll}\text { mi } 7 & \mathrm{ki}\rceil & \mathrm{ts}^{\mathrm{h}} \mathrm{u}-1 & \mathrm{kv}\rceil & \mathrm{grt} & \mathrm{sæ}-1 \\ \text { daughter } & \text { small } & \text { dem.prox } & \mathrm{cl} & \text { poss } & \text { blood }\end{array}$

'...the blood of the younger daughter...' (from 'Weresow' story)

The order in compounds is determiner + determined, but a few lexicalized items made of adjective + noun have the reverse order, e.g. 'dry field': Lijiang Naxi /py J-lu- - , Na /py ('dry' + 'field').

There is no gender or agreement. 
The counting system is decimal. The numeral and classifier follow the head noun. There are some tonal irregularities in numeral-plus-classifier phrases, which echo one another across dialects (Michaud 2011b).

Classifiers are relatively numerous; many still correspond transparently to a noun. Some 'self-classifiers' are used without a head noun: $\mathrm{Na} / \mathrm{d} \mathrm{w}-\mathrm{-}-\mathrm{so}\rfloor \mathrm{k}^{\mathrm{h}} \mathrm{y} / /$ 'several years' $\left(\right.$ not $/ *^{*} \mathrm{k}^{\mathrm{h}} \mathrm{v} 1$ dut-so」 $\left.\left.\mathrm{k}^{\mathrm{h}} \mathrm{y}\right\rfloor /\right)$.

There are proximal and distal demonstratives. The proximal demonstrative of $\mathrm{Na}, / \mathrm{ts}^{\mathrm{h}} \mathrm{uT} 7$, is homophonous with the $3^{\text {rd }}$ person singular pronoun, as is the distal demonstrative of Naxi, $/ \mathrm{t}^{\mathrm{h}} \mathrm{w}-1$. There are inclusive and exclusive pronouns for $2 \mathrm{PL}$, and collective forms referring to 'me and my kin', 'you and your kin', etc.

The clause relativizer in $\mathrm{Na}$ and Laze is /hĩ/:

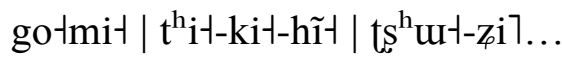

$$
\begin{aligned}
& \text { gołmit } \left.\quad \mathrm{t}^{\mathrm{h}} \mathrm{i} \quad \text { ki hi } \quad \mathrm{ts}^{\mathrm{h}} \mathrm{u}\right\rceil \text { zi1 } \\
& \text { younger_daughter durative give } \mathrm{nmlz} \text { dem.prox cl_of_households }
\end{aligned}
$$

'the household which the woman enters upon marriage...' (Yongning Na, 'Marriage of the Sister' story)

Naxi presents evidence of this nominalizer from rituals preserving archaic turns of phrase (Michaud 2011a, 99-100) but it has been replaced by the possessive, /grt/, in everyday language.

\subsubsection{Verb, verb phrase, and other predicates}

Directionality is expressed before the verb, by /grJ-/ 'upward', /mu」-/ 'downward' or /kæ-// 'to the front'.

Verb serialization is used for many constructions including resultatives, equivalents of Chinese ‘ $d e$ 得' constructions, and the expression of movement (Lidz 2010, 397-405). Imperatives are simply conveyed by intonational means: the syntactic structure is the same as for statements. The only verb that has distinct imperative form is 'go': Naxi /fy-t/, Na /hũ $-/$, Laze /hũ $7 /$ (the three forms are cognate; note that the Naxi form is now being replaced by the Chinese borrowing /fæ- $/$, from $f a ̄$ 發).

There exists a copula in all Naish languages. It is not used with adjectives. In $\mathrm{Na}$, it can be added after any verb to convey certainty (Lidz 2010, 354).

Adjectives can be considered as stative verbs: they "can take aspect marking, be negated, and can be modified by the intensifier" (Lidz 2010:362; the intensifier is /-z̧wæ $\lambda /$ in Na and /gjæ」-/ in Naxi). 


\section{Writing}

Section 3.1 presents examples of two varieties of the Naxi pictographic script. Section 3.2 places this script in historical perspective, along with the other traditional Naxi script: a syllabic writing system.

\subsection{Presentation of the pictographic script through an example}

The following excerpt is from a central ritual of the Naxi tradition: the funeral ritual for someone whose spouse is still alive. The deceased cannot - must not - take along her/his beloved(s) on the journey back to the ancestral home, and must therefore be accompanied instead by a chicken (sacrificed during the ritual; a rooster for a woman, a hen for a man). This text was copied and recited by Mr. Xí Shànghóng 习尚洪, in Rìshùwān 日树湾 village, Zhōngdiàn 中甸 Prefecture (now renamed Xiānggélǐlā 香格里拉; full administrative coordinates of the village: Sānbà xiāng, Dōngbà Xíngzhèng cūn, Rìshùwān zìráncūn 三坝乡 东坝行政村日树湾自然村). The text was recorded, transcribed and annotated by Zhōng Yàopíng. The correspondence between words and characters is not straightforward and requires a special explanatory apparatus. Words with a corresponding character are in bold; in the frequent case where a word is cued by a component of a character, that component is written above the word, but the word is not set in bold.
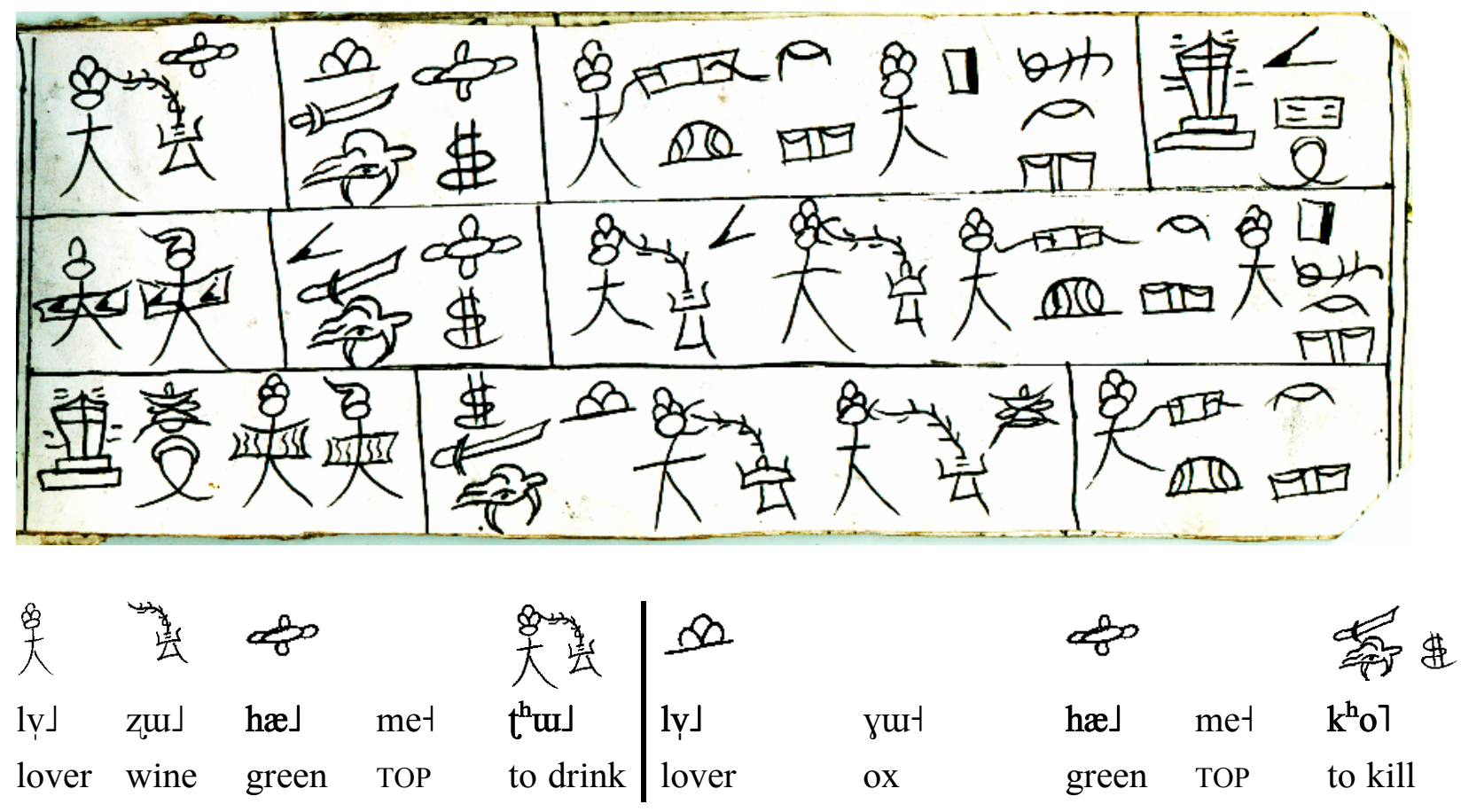

"The beloved drinks green wine, the beloved kills green oxen [the text describes the four sides of a mountain, each of which has its own color, which permeates human activities in 
that place; the deceased wanders through all four sides - i.e. everywhere - without finding her/his beloved/spouse];"

\begin{tabular}{|c|c|c|c|c|c|c|c|c|}
\hline 实 & 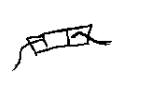 & 00 & $\infty$ & $\mathrm{BE}$ & 多 & $\square$ & $\theta+$ & $\infty$ \\
\hline 1 & $k^{h} \mathbf{y}^{\mathrm{h}}$ & $\mathrm{t}^{\mathrm{h}} \mathbf{v}^{-1}$ & mat & lwa & lỵ & tse 7 & $\mathrm{za}$ & mat \\
\hline jer & to shout & to come out & NEG & RES & lover & to meet & to come down & NEG \\
\hline
\end{tabular}
"when called, the beloved won't come out; the beloved won't come for the date."

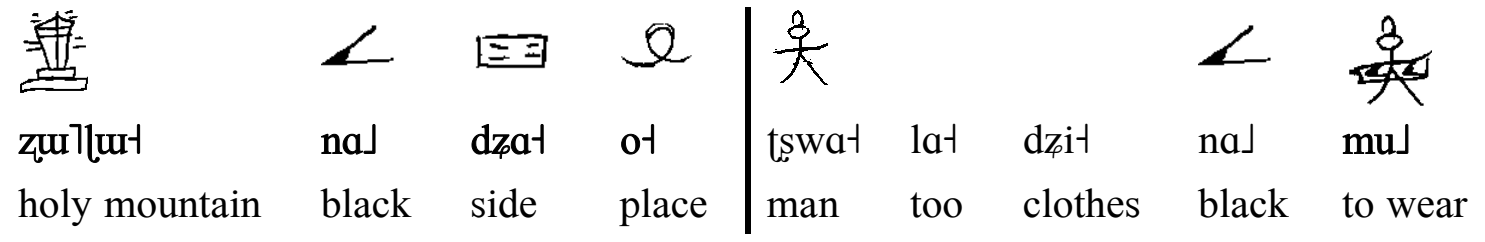

"On the black side of the holy mountain, [where] men wear black clothes,"

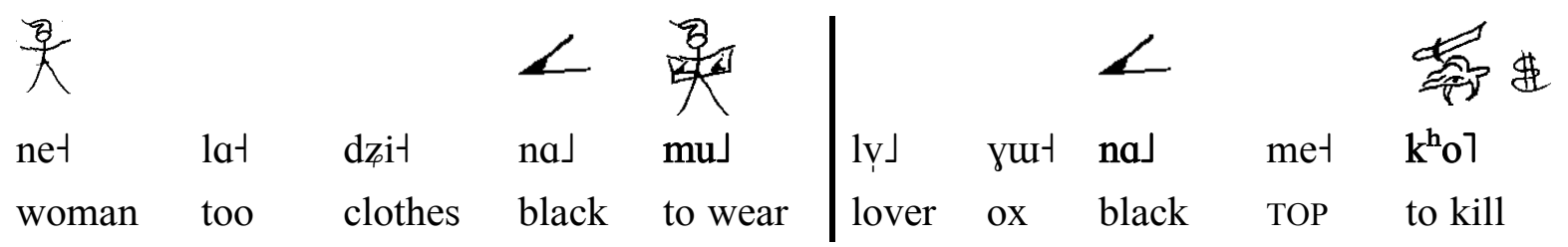

"and women likewise wear black clothes, the beloved kills black oxen,"

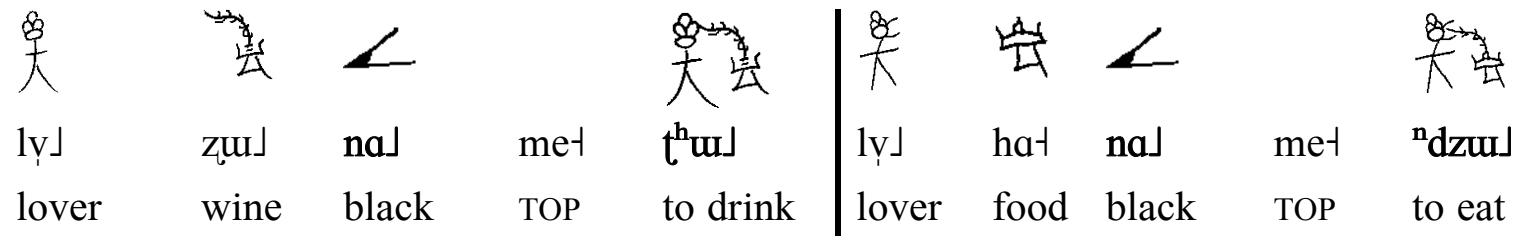

"the beloved drinks black wine, the beloved eats black food."

The text goes on: "When called, the beloved won't come out... On the yellow side of the holy mountain, where men wear yellow clothes, and women likewise wear yellow clothes..."

This page illustrates several creative possibilities of the pictographic script.

(i) Saving time and space by omitting some characters, e.g. 'clothes', sufficiently cued by the character 'to wear'. Rituals are orally learnt by rote, with the text serving as mnemonic; not all the words have a corresponding character. This is not due to an intrinsic limitation of the writing system: it would be possible to transcribe each word (lexical or grammatical) by a character. A recent book aiming to popularize the Naxi script for a Chinese-reading audience adopts a one-to-one correspondence between characters and syllables (Hé Lìmín 和 力民 2007), thereby sinicizing the Naxi writing system; this is a radical departure from traditional usage, but it demonstrates that the set of characters allows for an exhaustive transcription of the spoken language. 
(ii) Making phonetic use of characters. The character for 'lover', which appears several

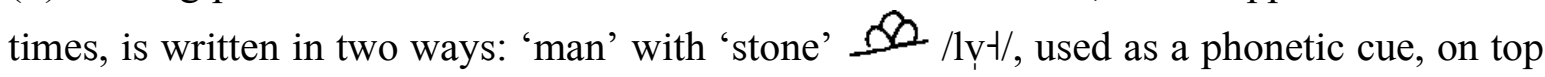
of it: 臬 ; or simply the character for 'stone', i.e. a phonetic loan character. 'To kill' \# comprises a semantic component composed of 'knife' (top) and the head of an ox turned upside down to express death (bottom). To this is added a phonetic element: \# $/ \mathrm{k}^{\mathrm{h}} \mathrm{o} /$ / 'railings', whose position is not fixed, witness the following layout, on the same page: The characters used for their phonetic value are not necessarily more stylized: for instance, the character for 'leftovers of butter-tea', $/ t^{\mathrm{h}} \mathrm{v} t /$, used here for 'to come out' $/ t^{\mathrm{h}} \mathrm{y} t /$, is written as 10 , not as the more stylized variant $\mathbf{2} \mathbf{x}$.

(iii) Making use of semantic associations. 'Yellow'/s $\rfloor /$ is indicated by means of 'gold', , which in its literal sense would be read as /hæ $\mathrm{J} /$.

(iv) Joining several characters. 'The lover drinks' is represented as 大帠. This was described above as two characters, 'lover' and 'wine', but the two are compounded in the actual text; in the variant towards the representation of a scene rather than a juxtaposition of characters. 'The lovers eat' is represented as $大$ 侌: a lover with an open mouth $K_{\text {plus 'food' }}$ spiked line as in 'to drink', where it represented the straw that was used to drink wine. The use of this line for 'to eat' is an innovation (not attested in any other text, to our knowledge), which transforms this line from a representation of a straw into an abstract representation of the transfer from container to mouth.

\subsection{History, main varieties, and geographic distribution}

Naxi scripts fall into two categories: the one illustrated in section 3.1, which for convenience can be called "pictographic" in a broad sense (though the composition of characters is highly diverse, and some have a phonetic component - as is common in logographic scripts), and syllabic. The pictographic script is currently referred to in Chinese as Dongba script (Dōngbāwén 東巴文) in China, after the name of the /to $-^{\mathrm{m}} \mathrm{ba} /$ / religion, because this writing system is almost exclusively used to write religious ritual texts. However, while the Naxi do refer to the pictographic books as 'To-mba books' [to- $\left.\left.1^{\mathrm{m}} \mathrm{ba}\right\lrcorner-\mathrm{t}^{\mathrm{h}} \mathrm{e}-\mathrm{yu}-1\right]$, the Naxi name of the

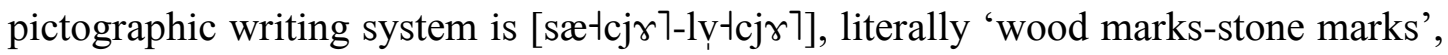
suggesting that the characters were originally written on wood and stone. There exist similarities between Naxi characters and Magdalenian-like rock paintings recently 
discovered along the Yangtze river, in the vicinity of the area which is traditionally recognized as the homeland of Naxi pictographic writing, north-northeast of Lijiang (Hé Lìmín 2003; on the state-of-the-art of archaeological research, see Taçon et al. 2010). While the possibility of chance similarities must be carefully considered, especially in the case of representations of animals, a strong argument comes from symbols that are tending towards abstraction. The Naxi pictograph for 'vagina' is shown below, to the right of an as yet undeciphered symbol found by the second author (Hé) among the rock paintings of Ninglang county (Nínglàng Àimǎndū 寧蒗艾满都 ).
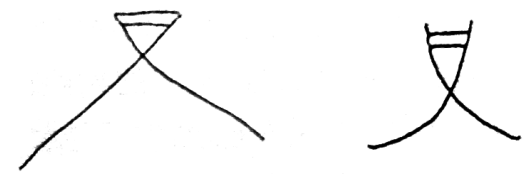

This strand of research is only beginning. Under the assumption that Tibeto-Burman migration into the area is not much earlier than the Qin dynasty (witness the vestiges of the Shíguān zàng 石棺葬 culture found in the Lijiang area), it must be hypothesized that the Tibeto-Burman invaders borrowed some symbols from rock paintings created by earlier inhabitants, who presumably spoke Austroasiatic languages. It has been suggested that Naxi writing was created by taking pictographs down from mountain tops into cities and entrusting them to ritual specialists - an appropriation and reinterpretation of the earlier local culture that may have been used to legitimize the conquerors' rule in the eyes of the conquered population (Mathieu 2003).

On the basis of the rituals' contents, the $7^{\text {th }}-10^{\text {th }}$ centuries AD have been mentioned as a likely period of rapid development of the written tradition (Hé Zhìwǔ 和志武 1985). Comparison between variants of characters suggests a gradual evolution towards greater abstraction, with (i) a simplification of some of the characters' shapes, (ii) the creation of an increasing number of composite characters, combining two elements one or both of which are used for their phonetic value, and (iii) a relative standardization of the elements used in characters (circles, dotted lines, etc). However, the greatest care must be exercised when labeling a variant as archaic, since we have not had the opportunity to see manuscripts dating back earlier than the $18^{\text {th }}$ century. The examples in Table 1 were copied by Zhong

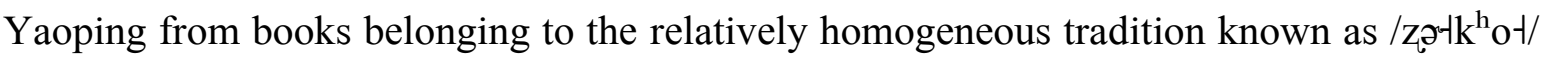
(pronunciation of the Lijiang plain) or $/ z_{2}-1 k^{h} a-\sim z u-k^{h} a-/$ (in Báidì 白地). The leftmost character is the one that looks to us most abstract and simplified. 
Table 1. Variants of characters

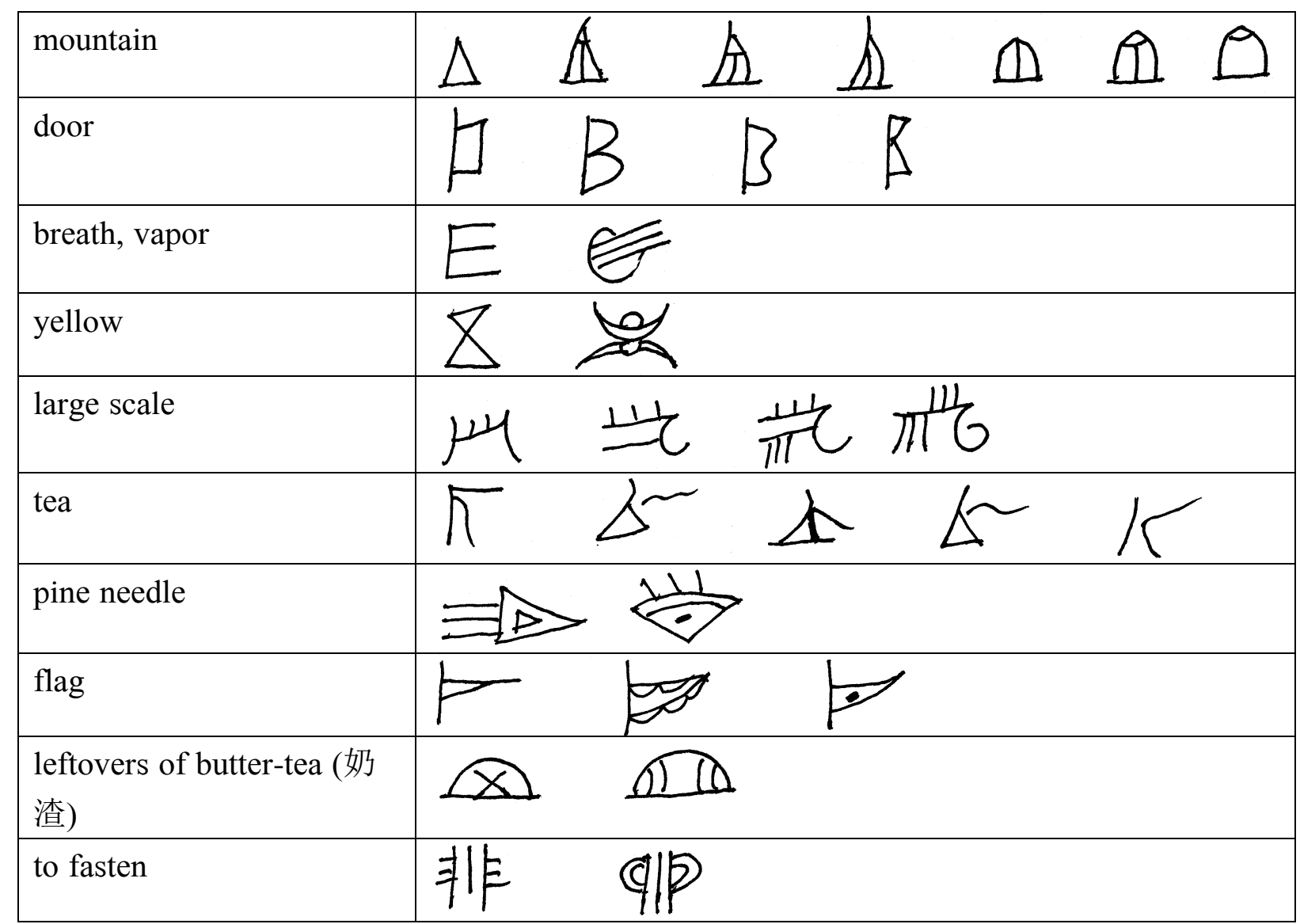

It can be proposed as a hypothesis that the To-mba tradition of the village of [bətdə-1] (Báidì 白地) was propagated throughout the Naxi area in the wake of the Naxi rulers' conquests, while local traditions continued to exist in remote areas, such as Jīnzhuāng 金庄 (endonym of the people: [bəthə」]) to the northwest of Lijiang, and the $/ \mathrm{zot}^{\mathrm{h}} \mathrm{\textrm {o }}-1 /$ (mentioned above) in the north-northeast. An overview of local varieties is presented by Hé Lìmín 和力民 (2010). The documentation of the pictographic traditions of these areas, which remains to be done, is crucial for the study of the development of the Naxi script.

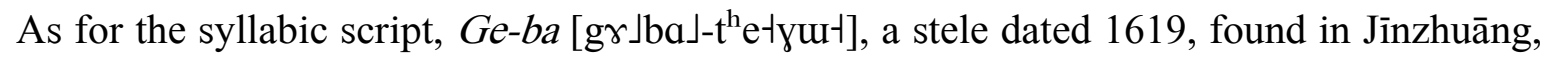
has Ge-ba, Tibetan and Chinese inscriptions, providing a terminus a quo for dating this script, which may have existed for a long time before then. This script, which has the inherent limitation of not transcribing lexical tone, did not become as widespread as the pictographic script. See Hé Jírén 和即仁 (2002) for an introduction, a collection of texts, a list of the $G e-b a$ symbols, and further references.

In the late $18^{\text {th }}$ century, a new variety of writing was created in the northwestern part of the Naish area (Wéixī 維西) by people now known locally as /ma-liilma-sat/, who migrated from an area without a writing system, further east (Yányuán 鹽源/Mùlǐ 木裡). Instead of adopting the local writing system holus-bolus, they created a syllabic script on the basis of about one hundred Naxi characters (Hé Zhìwǔ 和志武 1985, 168-170). Mention must also 
be made of a set of some forty signs used in Yǒngníng (in an area without pictographic books: see map) to refer to days and their symbolic attributes (Hé Xuézhèng 杨学政 1985). In the $20^{\text {th }}$ century, the pictographic tradition began to decline, at the same time as it became the object of academic scrutiny. Dictionaries of Naxi characters were published by Fāng Guóyú 方國瑜 and Hé Zhìwǔ 和志武 1995, Li Lin-ts'an 李霖灿, Chang K'un 張琨 and Ho Ts'ai 和才 (1953) and Rock 1963 (IPA equivalents for the latter's idiosyncratic phonetic transcription are provided in Michailovsky and Michaud 2006); there exist relatively numerous collections of texts, including a massive, 100-volume edition with standardized phonetic transcriptions and translations ( Nàx $\bar{l}$ dōngbā gǔji yìzhù quánjì 《纳西东巴古籍译 注全集》, 1999) prepared with the collaboration of the last generation of proficient To-mba practitioners, as well as earlier publications such as Fù Màojī 傅禁勣 1981.

As far as can be told from the present (less than ideally tidy) state of library catalogues, some 30,000 Naxi books are kept in libraries worldwide. Excluding variants of the same rituals, there would be on the order of 1,000 different rituals (Zhōngguó shăoshù mínzú gǔjí zǒngmù tíyào•Nàxīzújuăn 《中国少数民族古籍总目提要・纳西族卷》, 2003:2). But pictographic texts without a full philological apparatus are of little use for research, hence the great importance of in-depth documentation of the Naxi manuscripts in the few areas where these traditions still survive.

\section{References}

Bacot, Jacques, Les Mosso : Ethnographie des Mosso, leurs religions, leur langue et leur écriture, avec les documents historiques et géographiques relatifs à Li-kiang par Ed. Chavannes. Leiden: E.J. Brill, 1913.

Bradley, David, "Nahsi and Proto-Burmese-Lolo", Linguistics of the Tibeto-Burman Area 2/1, 1975, 93-150.

Collectively authored book (Zhōngguó shăoshù mínzú gǔjí zǒngmù tíyào•Nàxīzú juàn biānjí wěiyuánhuì 《中国少数民族古籍总目提要・纳西族卷》编辑委员会), Zhōngguó shăoshù mínzú gǔjí zǒngmù tíyào•Nàxīzú juàn 中国少数民族古籍总目提要・纳西族 卷 [Naxi volume of the Comprehensive table of contents and abstracts of ancient books of China's ethnic minorities]. Beijing: Zhōngguó dàbǎikē quánshū chūbănshè 中国大百科全书出版社, 2003.

Collectively authored book (Nàxī dōngbā gǔjí yìzhù quánjí biānwěihuì 《纳西东巴古籍译注 全集》编委会), Nàxī dōngbā gŭjí yìzhù quánjí 纳西东巴古籍译注全集 [Complete collection of Naxi Dongba ancient books, translated and annotated], Kūnmíng 昆明: Yúnnán rénmín chūbǎnshè 云南人民出版社 [Yunnan People’s Publishing House], 1999, 100 volumes. 
Fāng Guóyú 方國瑜 and Hé Zhìwǔ 和志武. 1995. Nàxī xiàngxíng wénzì pǔ 纳西象形文字 谱 [A Dictionary of Naxi Pictographic Characters]. Kūnmíng 昆明: Yúnnán rénmín chūbănshè 云南人民出版社 [Yunnan People's Publishing House], 1995.

Fù Màojī 傅檚勣, Wéixī Móxiē yánjiū 维西麼些语研究 [A Study of the Moso Language (Wei-Hsi Dialect), Part II: Grammar], Chóngqìng 重庆: Xīnán Liánhé Dàxué 西南联 合大学 [University of Western China], 1940.

Fù Màojī 傅禁勣, Nàxīyǔ túhuà wénzì “Bái biānfú qǔ jīng jị” yánjiūu 纳西语图画文字 “白 蝙蝠取经记”研究 [A study of a Naxi pictographic manuscript, “White Bat's Search for Sacred Books"]. Tokyo: Computational Analyses of Asian and African Languages: Monograph Series 6, 1981.

Gài Xìngzhī 蓋興之 and Jiāng Zhúyí 姜竹儀, “Nàxīyǔ zài Zàngmiănyǔzhōng dē dīwèi 纳西 语在藏缅语中的地位 [The Position of Naxi within Tibeto-Burman]”, Mínzú Yǔwén 民族语文 [Minority Languages of China] 1, 1990, 63-73.

Gūo Dàliè 郭大烈 and Hé Zhìwǔ 和志武, Nàxīzú sȟ̌ 纳西族史 [A History of the Naxi people], Chóngqìng : Sìchuān Mínzú Chūbănshè 四川民族出版社 [Sichuan Nationalities Publishing House], 1994 [2nd ed. 1999].

Hé Jírén 和即仁 and Jiāng Zhúyí 姜竹仪, Nàxĩyǔ jiănzhì 纳西语简志 [A Brief Monography on the Naxi Language] (Zhōngguó shăoshù mínzú yǔyán jiănzhì cóngshū 中国少数 民族语言简志丛书), Beijing: Mínzú Chūbǎnshè 民族出版社 [Nationalities Publishing House] 1985.

Hé Jírén 和即仁, Qiúqǔ zhānbǔ jīng 求取占卜经 [The Quest for Divination Books] (Yúnnán mínzú gǔjí cóngshū 云南民族古籍从书), Kūnmíng 昆明: Yúnnán mínzú chūbănshè 云南民族出版社[Yunnan Nationalities Publishing House], 2002.

Hé Jírén 和即仁, Mínzúyǔ wén lùnwénjí 民族语文论文集 [Collected papers by He Jiren], Kūnmíng 昆明: Yúnnán mínzú chūbănshè 云南民族出版社 [Yunnan Nationalities Publishing House], 2006.

Hé Lìmín 和力民 “Dōngbāwén yuányú jīnshājiāng yánhuà 东巴文源于金沙江岩画 [The Dongba script originates in rock paintings of the Yangtze river area]", in: Zhào Shìhóng 赵世红, ed., Dōngbā wénhuà yánjiūsuǒ lùnwén xuănjí 东巴文化研究所论 文选集 [Selected papers about the Dongba culture], Kūnmíng 昆明: Yúnnán mínzú chūbănshè 云南民族出版社 [Yunnan Nationalities Publishing House], 2003, 202209.

Hé Lìmín 和力民, Tōngsú Dōngbāwén 通俗东巴文 [Popular Dongba Script], Guangdong: Guangdong Keji Chubanshe 广东科技出版社 [Guangdong Technology Publishing House], 2007. 
Hé Lìmín 和力民, “Lùn Dōngbājiào de pàixì jí qí tèdiăn 论东巴教的派系及其特点 [About schools within the Dongba religion and their specificities]", in: Hé Lìmín Nàxĩxué Lùnjí 和力民纳西学论集 [Collected research paper about the Naxi by He Limin], Beijing: Mínzú chūbănshè 民族出版社 [Nationalities Publishing House], 2010, 145 160.

Hé Jiézhēn 和洁珍, ed., Nàxĩ yànyǔ jí 纳西谚语集 [A Collection of Naxi Proverbs], Kūnmíng 昆明: Yúnnán mínzú chūbănshè 云南民族出版社 [Yunnan People’s Publishing House], 2009.

Hé Zhìwǔ, “Nàxīzú de gǔwénzì hé dōngbājīng lèibié 纳西族的古文字和东巴经类别 [The ancient script of the Naxi, and a typology of Dongba manuscripts]”, in: Guō Dàliè 郭 大烈 and Yáng Shìguāng 杨世光, eds., Dōngbā wénhuà lùnjí 东巴文化论集

[Collected papers about Dongba culture], Kūnmíng 昆明: Yúnnán rénmín chūbănshè 云南人民出版社 [Yunnan People's Publishing House], 1985, 155-172.

Jacques, Guillaume, and Alexis Michaud, “Approaching the historical phonology of three highly eroded Sino-Tibetan languages: Naxi, Na and Laze”, Diachronica 28/4, 2011, $468-498$.

Li Lin-ts'an 李霖灿, Chang K'un 張琨 and Ho Ts'ai 和才, Móxiē xiàngxíng wénzì zìdiăn 麼些象形文字字典 [Dictionary of Moxie Pictographs], Hong Kong: Shuōwénshè 说 文社, 1953. Reprinted as: Nàxī xiàngxíng biāoyīn wénzì zìdiăn 纳西象形标音文字 字典 [Dictionary of Naxi Pictographic and Phonetic Characters], Kūnmíng 昆明: Yúnnán mínzú chūbănshè 云南民族出版社 [Yunnan People’s Publishing House], 2001.

Ľ̌ Yǒngsuì 李永燧, Miănyí yǔyinn yùnxué 缅彝语音韵学 [Burmo-Yi Phonology] ( Zhōngguó Shèhuì Kēxuéyuàn lăonián xuézhě wénkù 中国社会科学院老年学者文 库 [Library of research by elderly scholars at China's Academy of Social Sciences]), Beijing: shèhuì kēxué wénxiàn chūbănshè 社会科学文献出版社 [Social Sciences Academic Press], 2010.

Lidz, Liberty, A Descriptive Grammar of Yongning Na (Mosuo), Ph. D. dissertation, Austin: University of Texas, Department of linguistics (2010). Available: https://repositories.lib.utexas.edu/bitstream/handle/2152/ETD-UT-2010-122643/LIDZ-DISSERTATION.pdf.

Mathieu, Christine, A History and Anthropological Study of the Ancient Kingdoms of the Sino-Tibetan Borderland - Naxi and Mosuo (Mellen Studies in Anthropology, 11), Lewiston, NY: Edwin Mellen Pr., 2003. 
Matisoff, James A. "The Mother of All Morphemes: Augmentatives and Diminutives in Areal and Universal Perspective", in: Martha Ratliff and Eric Schiller, eds., Papers from the First Annual Meeting of the Southeast Asian Linguistics Society (SEALS), Tempe, Arizona: Arizona State University, Program for Southeast Asian Studies, 1992, 293-349.

Mazaudon, Martine, “Tamang”, in: Graham Thurgood and Randy LaPolla, eds., The SinoTibetan Languages, London: Routledge, 2003, 291-314.

Michailovsky, Boyd, and Alexis Michaud, "Syllabic inventory of a Western Naxi dialect, and correspondence with Joseph F. Rock's transcriptions", Cahiers de Linguistique Asie Orientale 35/1, 2006, 3-21.

Michaud, Alexis, "Tonal Reassociation and Rising Tonal Contours in Naxi”, Linguistics of the Tibeto-Burman Area 29/1, 2006, 61-94.

Michaud, Alexis, "Pictographs and the Language of Naxi Rituals", in: Christine Mathieu and Cindy Ho, eds., Quentin Roosevelt's China. Ancestral Realms of the Naxi, Stuttgart: Arnoldsche Art Publishers, 2011a, 92-101.

Michaud, Alexis, "The Tones of Numerals and Numeral-plus-classifier Phrases: On Structural Similarities Between Naxi, Na and Laze", Linguistics of the TibetoBurman Area 34/1, 2011b, 1-26.

Michaud, Alexis, and He Xueguang, "Reassociated Tones and Coalescent Syllables in Naxi (Tibeto-Burman)", Journal of the International Phonetic Association 37/3, 2007, $237-255$.

Michaud, Alexis, and Guillaume Jacques, "The Phonology of Laze: Phonemic analysis, syllabic inventory, and a short word list”, Yuyanxue Luncong 语言学论丛 45, 2012, 196-230.

Michaud, Alexis, and Latami Dashi, "A Description of Endangered Phonemic Oppositions in Mosuo (Yongning Na)", in: Tjeerd De Graaf, Xu Shixuan and Cecilia Brassett, eds., Issues of language endangerment: Selected papers from the Academic Session on Issues of Language Endangerment, 16th Int. Conf. of Anthropological and Ethnological Sciences (ICAES 2009), Beijing: Zhīshi chănquán chūbǎnshè 知识产 权出版社 [Intellectual property publishing house], 2011, 55-71.

Michaud, Alexis, and Jacqueline Vaissière, "The phonetic evolution of reduplicated expressions: Reduplication, lexical tones and prosody in $\mathrm{Na}$ (Naxi)", in Proceedings of the 16th International Congress of Phonetic Sciences, Saarbrücken, 2007, 801-804. 
Pinson, Thomas M., Naxi-Chinese-English Glossary, with English and Chinese Indexes, Dallas: The Summer Institute of Linguistics, 1998

Rock, Joseph, A Na-Khi -- English Encyclopedic Dictionary (Serie Orientale Roma, No. 28), Rome: Instituto Italiano per il Medio ed Estremo Oriente, 1963.

Shafer, Robert, "Classification of the Sino-Tibetan Languages", Word 11, 1955, 94-111.

Taçon, Paul S.C., Li Gang, Yang Decong, Sally K. May, Liu Hong, Maxime Aubert, Ji Xueping, Darren Curnoe, and Andy I.R. Herries, "Naturalism, Nature and Questions of Style in Jinsha River Rock Art, Northwest Yunnan, China", Cambridge Archaeological Journal 20/1, 2010, 67-86.

Yang Zhenhong, "An Overview of the Mosuo Language", Linguistics of the Tibeto-Burman Area 32/2, 2009, 1-44.

Yáng Xuézhèng 杨学政, “Dábājiào yǔ Dōngbājiào břjiào yánjiū 达巴教与东巴教比较研究 [Comparative research on the Daba religion and the Dongba religion]”, in: Zōngjiào lùngăo 宗教论稿, Kūnmíng 昆明: Yúnnán rénmín chūbănshè 云南人民出版社 [Yunnan People's Publishing House], 1985, 103-196.

INDEX TERMS: Sino-Tibetan; Naxi; Na; Laze; Naish; pictographic script

SUMMARY: This is a presentation of the state of the art of research on languages of the Naish subgroup of Sino-Tibetan, referred to as "Naxi dialects" in Chinese scholarship.

\section{AUTHOR BIOGRAPHY:}

Alexis Michaud is a researcher at CNRS (France). He has been conducting fieldwork on Naish languages (Naxi, $\mathrm{Na}$, and Laze) since 2002, aiming to produce in-depth documentation in the course of his study of these languages. His main research interests are phonetics/phonology (especially tonology) and historical phonology.

Hé Lìmín 和力民 is a researcher at the Dongba Culture Research Institute (Lijiang, China). He is an expert on the Naxi scripts, and a practitioner of Naxi rituals. In addition to his activity as a researcher, he is committed to the maintenance of the Naxi scripts; he cofounded several schools in Lijiang Municipality where these scripts are now taught. 
Zhōng Yàopíng 钟耀萍 is a researcher at the Chinese Academy of Social Sciences (Beijing, China). She devoted her $\mathrm{Ph}$. D. dissertation to little-documented varieties of the Naxi pictographic script that are still alive among speakers of Naish languages in remote areas along the Yangtze river, North-North-East of Lijiang. 